\title{
Landscape-dynamic aspects of soil formation in the Lena River Delta
}

\author{
Vyacheslav Polyakov ${ }^{1,2,3^{*}}$, Ksenia Orlova $^{1}$, Evgeny Abakumov ${ }^{1 *}$ \\ ${ }^{1}$ Saint Petersburg State University, University Embankment, 7/9, Saint-Petersburg, \\ 199034, Russia \\ ${ }^{2}$ FSBI "Arctic and Antarctic Research Institute”, Beringa 38, Saint-Petersburg, 199397, \\ Russia \\ ${ }^{3}$ Department of Soil Science and Agrochemistry, Faculty of Agriculture, Saint-Petersburg \\ State Agrarian University, Petersburg Highway 2, Pushkin, Saint-Petersburg, 196601, \\ Russia
}

\begin{abstract}
This article provides data on the study of pedodiversity and pecularities of soils and their spatial distribution in the territory of the Lena River Delta (Siberia, Russia). Special reference to geogenic factors of soil formation in the pedoenvironment are made. The main patterns of soil distribution in different geomorphic positions for Samoilovsky, Arga-Belir-Aryta, Kurungnakh and Hardang islands are discussed. The soil catenas of the 4 investigated islands are given as a reliable representation of the formation of soils and the development of soil-forming processes in various types of relief and geomorphological features. Soils are represented mainly by the following groups: Fluvisols, Umbrisols, Podzols, Cryosols, Histosols, Gleysols, which are closely related to the geomorphic terraces of the delta.
\end{abstract}

Key words: soil catenas, pedodiversity, soil organic matter, Lena River Delta

DOI: $10.5817 / \mathrm{CPR} 2018-2-22$

\section{Introduction}

About $60 \%$ of the Russian land surface is underlain by permafrost. Degradation of permafrost is affected by climate change but also results in important feedbacks to climate change. The characterization of permafrost-underlain areas, permafrostaffected soils, and their soil organic carbon (SOC) and nitrogen $(\mathrm{N})$ stocks are important to understand interactions of the bio- geochemical cycle with the global climate. Permafrost-affected soils have to be considered as a globally important element of the cryosphere within the global climate system (Zubrzycki et al. 2013, 2014). The investigation of soils catenas is the right tool to understand the distribution of soils in space. It can provide the data of main soil-forming processes on wide areas.

Received August 2, 2018, accepted January 30, 2019.

*Corresponding author: Polyakov<slavon6985@gmail.com>, Abakumov<e.abakumov@spbu.ru> Acknowledgements: This work was supported by a grant of Saint-Petersburg State University

"Urbanized ecosystems of the Russian Arctic: dynamics, state and sustainable development" and Russian Foundation for Basic Research, project No 16-34-60010. 
The Lena River Delta is covered by a network of numerous small and large channels and has more than 1000 islands. The Lena delta can be defined in three different geomorphic terraces and an active flooded level. The active flooded level and the first terrace $(1-12 \mathrm{~m})$ is the very young part of the river delta. The first terrace was formed during the Middle Holocene and is mainly represented in the eastern part of the Lena delta (Bolshiyanov et al. 2013). The second terrace $(11-30 \mathrm{~m})$ formed in the interval between the late Pleistocene and the early Holocene and includes about $23 \%$ of the delta territory and is characterized by sand fractions and a small amount of ice. The polygonal relief is less pronounced, a large number of thermokarst lakes is typical for this territory. The third terrace $(30-60 \mathrm{~m})$ is the oldest terrace in the Lena delta. It is not a river delta block, it is the eroded remnant of the late Pleistocene fine-grained glacial material that accumulated in front of the Chekanovo and Kharulakh mountain ranges. The surface of the third terrace is a polygonal terrain, due to the formation of ice veins and a net of permafrost tundra polygons with developed thermokarst processes (Bolshiyanov et al. 2013).

Soils form under the influence of zonal factors and alluvial processes. River processes are associated with the formation of Fluvisols where fresh alluvium deposits and

\section{Material and Methods}

\section{Study area}

The study area is located in the delta of the Lena River (Fig. 1). The study areas are located in the central and south-eastern parts of the delta.

The Lena River Delta is the largest northern delta in the world; it is located in the Arctic zone and has an area of about $29,630 \mathrm{~km}^{2}$. It has a significant impact on the water regime of the Arctic Ocean, flooding of territories annually happens. Zonal cryogenesis (cryogenic mass exchange) includes such processes as cryogenic mass exchange (also called cryoturbation), gleying, redistribution of humic substances along the profile, thermokarst, solifluction. Peat formation and peat accumulation are also inherent in these soils. A high rate of biological activity and the formation of organomineral compounds that include mobile forms of ferrum and aluminum are determined here. The significant influence of delta soils on exchange processes in the ocean-atmosphere system is noted, due to the receipt of a large amounts of humic substances from the soil into the Arctic Ocean. A high content of carbon is obtained in soils confined to the Arctic subzone. The soils are confined to the area of continuous permafrost, which is a biogeochemical barrier in the soil where the accumulation of organomineral compounds occurs (Nechaeva 1994, Antonov 1957, Pesterev 2013, Cauwet et Sidorov 1996, Lara et al. 1998).

The aim of this study is to investigate the spatial distribution of soils in the delta. For this purpose, the following tasks were set: 1 . Investigating soil diversity in different geomorphological positions. 2. Identification of patterns of soil distribution in different geomorphological positions. 3 . Topographic soil profiling of the investigated islands.

since a large amount of fresh water from the delta flows in the least salty ocean of our planet. The delta was formed by the geomorphic activity of the river: removal of sediments, erosion, abrasion under the influence of sea level fluctuations and movements of the earth crust (Bolshiyanov et al. 2013). 

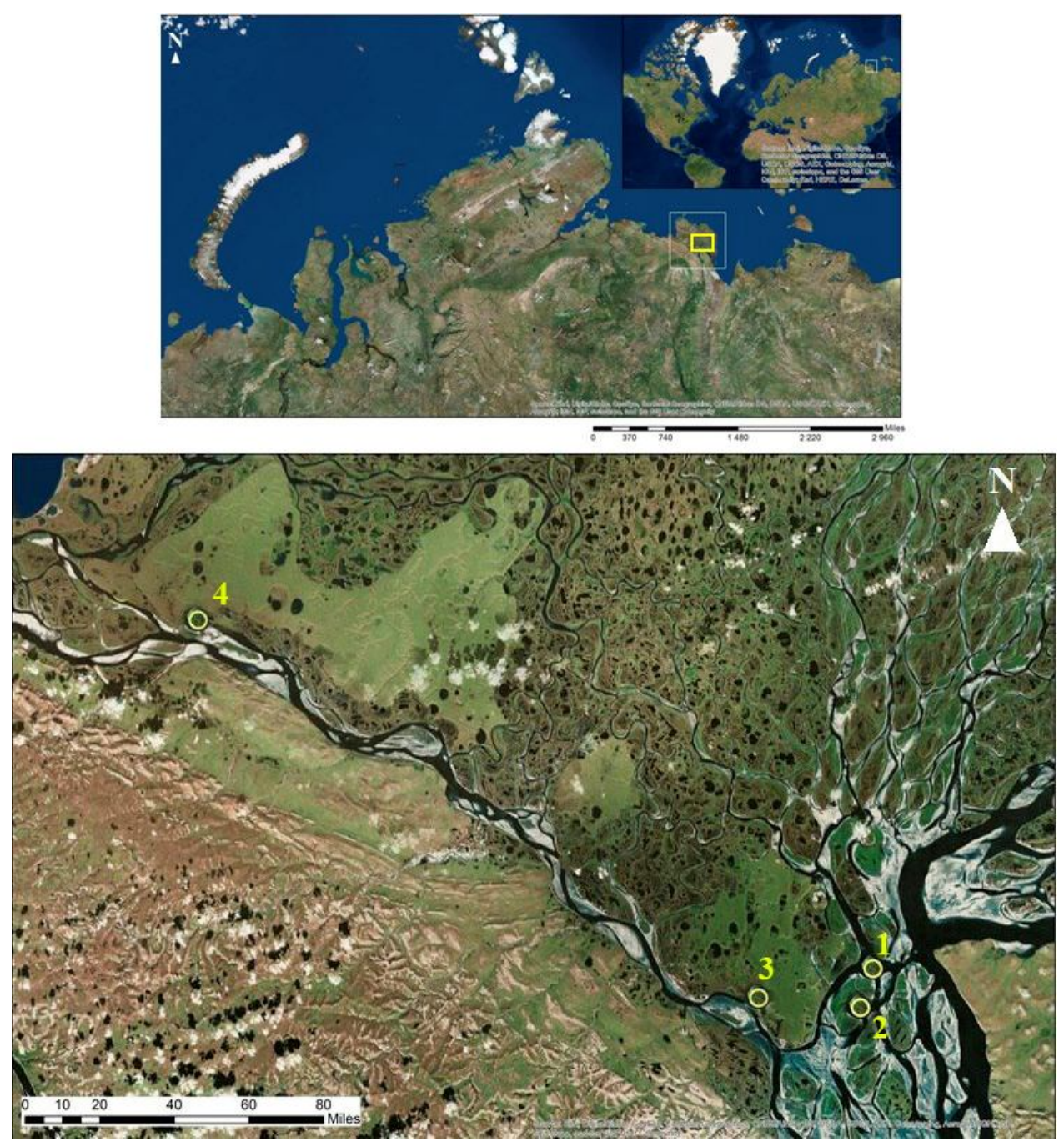

Fig. 1. The investigated area. The Lena River Delta.

The Lena River Delta is located in a zone with an Arctic maritime climate. The climatic characteristics are given from observations from the polar meteorological stations Tiksi, Stolb, Ust-Olenek and NIS "Samoilovsky Island". The average annual temperature is $-13^{\circ} \mathrm{C}$, the average January temperature is $-32^{\circ} \mathrm{C}$, the average July temperature is $-6.5^{\circ} \mathrm{C}$. Analysis of the data showed that the trends of surface air temperature and pressure in all months of the year are slight and insignificant. However, the course of extreme temperatures has a significant trend, during the observation period the maximum air temperatures decrease, which is associated with the effect of cloudiness on the radiation heating of the lower atmosphere layer. This indicates that in winter the grounds are less cooled and in summer they are less warmed up.

The annual amount of precipitation is $190 \mathrm{~mm}$. Averaged daily summer evapora- 
tion rates of $1.3 \mathrm{~mm} \mathrm{day}^{-1}$ are comparable to those for other sites in the Arctic (Boike et al. 2013). Most of the landscape is characterized by the presence of permafrostaffected soils from a depth of about one meter, the depth of the seasonally thawed active layer is variable, on silty loam it can reach $30 \mathrm{~cm}$ at the end of August, and on sediments of the fine texture class reach up to 1 meter (Bolshiyanov et al. 2013, Galabala 1987, Ivanov 1963).

The tundra vegetation of various types covers the land ecosystems of the Lena River Delta. The main components are grasses, forbs, sedges, mosses, lichens and shrubs. A characteristic feature of the tundra is the absence of forest. The vegetation cover is not continuous ("spotted tundra") - clustered in space. The grass-sedge-mossy communities prevail, in the depressions of the relief there are the grassy polygonal marshes. The bryophyta communities predominate on loamy soils, and lichen groups predominate on coarse stony soils. Near lakes cottongrass-sedge communities often replace moss-lichen vegetation. On the warm southern slopes on drained light texture soils and in the valley of the river there are areas with grassy vegetation (tundra meadows and floodplain meadows). Certain types of vegetation associate with different positions in the relief, so to the wet tundra (with wet centers in polygons, negative forms of relief) are confined - Drepanocladus revolvens, Meesia triquetra, Rhizomnium punctatum, Calliergon giganteum, Carex chordorrhiza, Comarum palustre, Pedicularis sudetica. Dry tundra (well drained positions) - Hylocomium splendens, Dryas punctata, Peltigera, Polygonum viviparum, Saxifraga punctata, Astragalus frigidus, Luzula tundricola, Lagotis glauca, Saxifraga hirculus, Valeriana capitata. Floodplain meadows - Salix glauca/reptans /lanata, Equisetum sp., Alopecurus alpinus, Festuca rubra, Deschampsia. Flooded areas of small lakes - Arctophila fulva (Boike et al. 2013, Kutzbach et al. 2004, Schneider et al. 2009).
The investigated islands are confined to the $1^{\text {st }}$ and $3^{\text {rd }}$ geomorphological terraces. We selected several islands for research.

Samoilovsky Island $(72.370 \mathrm{~N} ; 126.467$ E), where the research station "Samoilovsky" locates, is situated in the area of the first terrace and is periodically flooded with river water. The island covers an area of about $5 \mathrm{~km}^{2}$. Recent erosion and eolian processes formed the western part. Ice wedges and small thermokarst lakes represent the eastern part. The island consists of heterogeneous deposits typical for the Lena delta (clayic, siltic, loamic, arenic patterns), which indicates a changeable condition of sedimentation.

Arga-Belir-Aryta Island $(72.382 \mathrm{~N}$; 126.427 E) is located slightly west of Samoilovsky Island and has a height of up to 10 meters. It is composed of sandy deposits and the relief is characterized by hummocks and depressions within $10-20 \mathrm{~cm}$. It also belongs to the first terrace and experience seasonal flooding. There is also second terrace on this island, it is composed the sands (Bolshiyanov et al. 2013).

Kurungnakh Island $(72.476$ N; 126.279 E) is located the central part of the Lena River Delta and is composed of sediments of the ice complex and underlying sands. In terms of soil formation, the island conditions are similar to Samoilovsky Island, the first terrace experiences seasonal flooding, and on the third terrace with ice complex, zonal processes of soil formation are developed.

Hardang Island $(72.46 \mathrm{~N} ; 123.56 \mathrm{E})$ locates in the western part of the delta, up to 45 meters high, on top is composed of the ice complex, with a poorly developed moss cover; the thermokarst basins and local erosion-thermokarst valleys characterize the relief. The ice complex is underlain by horizontal layered quartz sands and silts containing plant remains, there are inclusions of ice veins, in some layers pebbles, small particles of quartz, jasper, carnelian are accumulated, as a result of fluvial processes of destruction of sands. 


\section{Field methods}

Material of this investigation are the data collected during two expeditions within the project "Lena River Delta" in 20152016 and 2018, organized by Arctic and Antarctic research institute. The soil samples were taken to represent the spatial pattern of the vegetation cover and the position in the landscape, the total number of soils samples is 150 . Soil samples were selected in various elements of the landforms. Several profiles were made in the areas subject to annual flooding and the places of the already-released conditions.

\section{Laboratory methods}

The dried samples were grounded passed through a $1 \mathrm{~mm}$ sieve. Soil samples were selected for each horizon to analyze physical and chemical properties. Analyses were conducted in the certified laboratory of St. Petersburg State University at the Department of Applied Ecology, Russia. Soils were analyzed according to the following methods: determination of actual acidity $\left(\mathrm{pH}_{\mathrm{H} 2 \mathrm{O}}\right)$, potential acidity $\left.\mathrm{CaCl}_{2}\right)$, by a stationary $\mathrm{pH}$ meter in aqueous solution and $1 \mathrm{~N} \mathrm{CaCl}_{2}$ solution, respectively. The microbiological activity of soils, the basal respiration, using incubation chambers was determined (Kimble et Follett 2001). To eval-

\section{Results}

We conclude from our study, that the soil catenas of the Samoilovsky, ArgaBelir-Aryta, Kurungnakh and Hardang islands are organized complicatedly.

Soil catenas laid from the edge of the water and passed inland of the islands. Thus, it is possible to describe and compare the soils of both the first and second geomorphological terraces. Soil description
Soil profiles were located in various elements of the landscape. They were expressed in following forms: micro depressions, hills, flooded areas and slopes of terraces. The investigated soils were classified according to the WRB ([1] - World reference base for soil resources, 2014). Soil trenches were prepared in various geomorphological positions, depending on the terraces and meso- and microrelief. Thus, we were able to cover the greater part of the study area and describe the soil diversity. The flora of the study areas was also investigated.

uate the volumetric content of carbon in the fine earth we had used data of "dry combustion" (Cco2). The determination of $\mathrm{Cco} 2$ is based on sample direct combustion and further evaluation of emitted $\mathrm{CO}_{2}$ by chromatography. During oxidation all the organic carbon turns into carbon dioxide. Further on, in resulting products of combustion utilized from chlorides and other halogens, the measurement of carbon dioxide takes place (Abakumov et Popov 2005, Polyakov et al. 2017). Cco2 and N content were determined using an element analyzer (Euro EA3028-HT Analyser, Italy) with dry combustion procedure.

are presented in Table 1

The soil diversity of Samoilovsky Island is represented by Fluvisols, Umbrisols, Podzols, Cryosols, Histosols, Gleysols. There are remnants of the ice complexes with evident features of erosion and surface transformation (Bolshiyanov et al. 2013). The spatial distribution of soils is shown in Fig. 2. 


\begin{tabular}{|c|c|c|c|c|}
\hline Soil Group & $\begin{array}{l}\text { Soils with } \\
\text { Qualifers }\end{array}$ & Horizon & $\begin{array}{l}\text { Depth } \\
\text { (cm) }\end{array}$ & Soil horizon description \\
\hline \multicolumn{5}{|c|}{ Samoilovsky Island } \\
\hline \multirow{3}{*}{ Fluvisol } & \multirow{3}{*}{$\begin{array}{l}\text { Stagnic } \\
\text { Fluvisol }\end{array}$} & Fluvic(1) & $0-5$ & 7,5 YR 7/3 sandy loam, roots \\
\hline & & Fluvic(2) & $5-46$ & 7,5 YR 6/3 loam, roots \\
\hline & & Stagnic & $46-71$ & 7,5 YR 4/4 red spots, loam \\
\hline \multirow{2}{*}{ Umbrisol } & \multirow{2}{*}{$\begin{array}{c}\text { Fluvic } \\
\text { Umbrisol }\end{array}$} & Fluvic & $0-9$ & 7,5 YR 7/3 sandy loam, roots \\
\hline & & Umbric & $9-17$ & 5 YR 6/6, loam \\
\hline \multirow{3}{*}{ Podzol } & \multirow{3}{*}{$\begin{array}{l}\text { Umbric Entic- } \\
\text { Podzol }\end{array}$} & $\mathrm{O}$ & $0-4$ & 10 YR 4/3 organic matter \\
\hline & & Umbric & $4-16$ & 5 YR 6/6, loam \\
\hline & & Spodic & $16-28$ & 5 YR 4/4 loam, red spots \\
\hline \multirow{3}{*}{ Cryosol } & \multirow{3}{*}{$\begin{array}{l}\text { Umbric } \\
\text { Cryosols } \\
\text { (Fluvic) }\end{array}$} & $\mathrm{O}$ & $0-10$ & 10 YR $4 / 3$ organic matter \\
\hline & & Umbric & $10-15$ & 5 YR 6/6, loam \\
\hline & & Cryic & $15-17$ & 10YR 6/1 loam, oxidized \\
\hline Histosol & $\begin{array}{l}\begin{array}{l}\text { Histosol } \\
\text { (Fluvic) }\end{array} \\
\end{array}$ & Histic & $0-14$ & 10YR 3/2 organic matter \\
\hline \multirow{2}{*}{ Gleysol } & \multirow{2}{*}{ Folic Gleysol } & Folic & $0-10$ & 10YR 3/2 organic matter \\
\hline & & Gleyic & $10-30$ & Gley 2 6/10BG loam, rusty spots \\
\hline \multicolumn{5}{|c|}{ Arga-Belir-Aryta Island } \\
\hline \multirow[b]{2}{*}{ Fluvisol } & \multirow{2}{*}{$\begin{array}{l}\text { Stagnic } \\
\text { Fluvisol } \\
\text { (arenic) }\end{array}$} & Fluvic & $0-18$ & 7,5 YR 6/3 arenic, roots \\
\hline & & Stagnic & $18-52$ & 10 YR 6/1 arenic, rusty spots \\
\hline Umbrisol & $\begin{array}{l}\text { Umbrisol } \\
\text { (arenic) }\end{array}$ & Umbric & $0-14$ & 7,5 YR 7/1 sand \\
\hline \multirow{2}{*}{ Cryosol } & \multirow{2}{*}{$\begin{array}{l}\text { Umbric } \\
\text { Cryosol }\end{array}$} & Umbric & $0-12$ & 7,5 YR 7/3 sandy loam, roots \\
\hline & & Cryic & $12-39$ & 7,5 YR 6/1 sandy loam, rusty spots \\
\hline \multicolumn{5}{|c|}{ Kurungnakh Island } \\
\hline \multirow{2}{*}{ Umbrisol } & \multirow{2}{*}{$\begin{array}{l}\text { Umbrisol } \\
\text { (loamic) }\end{array}$} & $\mathrm{O}$ & $0-6$ & 10YR $3 / 2$ organic matter \\
\hline & & Umbric & $6-11$ & 7,5 YR 7/3 loam \\
\hline \multirow{2}{*}{ Podzol (1) } & \multirow{2}{*}{\begin{tabular}{|c|} 
Stagnic Entic- \\
Podzol
\end{tabular}} & $\mathrm{O}$ & $0-13$ & 10YR 3/2 organic matter \\
\hline & & Spodic & $13-22$ & 10YR 6/3 loam, oxidized \\
\hline \multirow{2}{*}{ Podzol (2) } & \multirow{2}{*}{$\begin{array}{c}\text { Umbric Entic- } \\
\text { Podzol }\end{array}$} & Umbric & $0-10$ & 7,5 YR 7/3 loam \\
\hline & & Spodic & $10-32$ & 7,5YR 6/4 rusty streaks \\
\hline \multirow{3}{*}{ Cryosol } & \multirow{3}{*}{$\begin{array}{l}\text { Umbric } \\
\text { Cryosol }\end{array}$} & $\mathrm{O}$ & $0-10$ & 10YR 3/2 organic matter \\
\hline & & Umbric & $10-15$ & 7,5 YR 7/1 sand \\
\hline & & Cryic & $15-17$ & 10YR 6/3 loam, rusty spots \\
\hline Histosol (1) & $\begin{array}{l}\text { Subaquatic } \\
\text { Histisol }\end{array}$ & Histic & $0-13$ & $10 \mathrm{YR} 3 / 2$ organic matter \\
\hline \multirow[t]{2}{*}{ Histosol (2) } & \multirow[t]{2}{*}{ Cryic Histosol } & Histic (1) & $0-15$ & 10YR $3 / 2$ organic matter \\
\hline & & Histic (2) & $15-18$ & 10YR 3/1 organic matter \\
\hline
\end{tabular}




\begin{tabular}{|c|c|c|c|c|}
\hline & & Cryic & $18-22$ & 7,5YR 4/3 loam, rusty spots \\
\hline \multirow{2}{*}{ Gleysol } & \multirow{2}{*}{$\begin{array}{c}\text { Gleysol } \\
\text { (loamic) }\end{array}$} & $\mathrm{O}$ & $0-5$ & 10YR $3 / 2$ organic matter \\
\hline & & Gleyic & $5-30$ & Gley 2 5/10BG loam, rusty spots \\
\hline \multicolumn{5}{|c|}{ Hardang Island } \\
\hline \multirow{3}{*}{ Fluvisol } & \multirow{3}{*}{$\begin{array}{l}\text { Gleyic } \\
\text { Fluvisol }\end{array}$} & Fluvic & $0-5$ & 7,5YR 6/3 loam, roots \\
\hline & & Fluvic & $5-31$ & 7,5 YR 7/4 sand, roots \\
\hline & & Gleyic & $31-65$ & Gley1 3/10Y loam \\
\hline \multirow{3}{*}{ Umbrisol } & \multirow{3}{*}{$\begin{array}{c}\text { Gleyic } \\
\text { Umbrisols }\end{array}$} & $\mathrm{O}$ & $0-7$ & 10YR 3/2 organic matter \\
\hline & & Umbric & $7-30$ & 7,5 YR 7/1 sand \\
\hline & & Gleyic & $30-60$ & 7,5 YR 5/3 loam, wet, rusty spots \\
\hline \multirow{4}{*}{ Cryosol } & \multirow{4}{*}{$\begin{array}{c}\text { Umbric Turbic } \\
\text { Cryosol }\end{array}$} & $\mathrm{O}$ & $0-7$ & 10YR 3/2 organic matter \\
\hline & & Umbric & $7-16$ & 7,5 YR 7/1 sand \\
\hline & & Turbic & $16-27$ & 7,5 YR $8 / 3$ stratified sand of \\
\hline & & Cryic & $27-35$ & 10 YR 6/1 loam, rusty spots \\
\hline \multirow{2}{*}{ Gleysol } & \multirow{2}{*}{ Folic Gleysol } & Folic & $0-3$ & 10YR 3/2 organic matter \\
\hline & & Gleyic & $3-18$ & Gley $12,5 / \mathrm{N}$ loam \\
\hline
\end{tabular}

Table 1. Soil description from study island from the Lena River Delta.

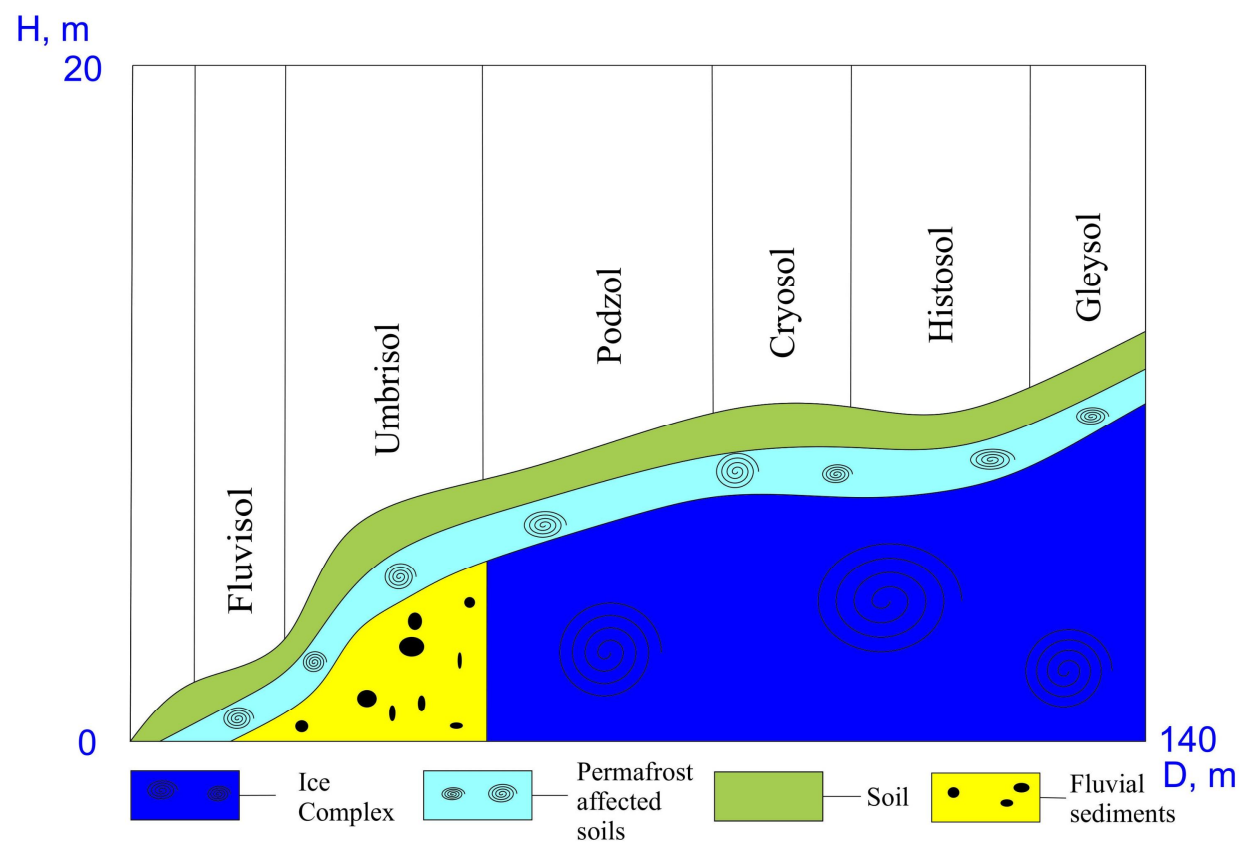

Fig. 2. The soil catena of Samoilovsky Island. 
This distribution is quite typical for river deltas, areas subject to the influence of the alluvial and flooding processes are characterized by the accumulation of river alluvium, here the soils of the Fluvisols group form, the stratification of soil horizons develops, the organic horizons change with lenses of sand and clays, also buried organic horizons present. The Umbrisols group locate mainly on an island in an area that has been recently subject to a flooding processes in the recent past, it retains the features of a soil precursor - Fluvisols. In terms of the physical properties of the soil, these soils have identical characteristics, but within Umbrisols group humus accumulation is more pronounced they are not under the influence of annual flooding and alluvial processes, which allows the accumulation of organic matter. The soils of the Cryosols group form on the tops of the hills and also on drained positions, a characteristic feature of this group is cryogenic mass exchange, the depth of the active layer is extremely small and reaches an average of $30 \mathrm{~cm}$. These soils are zonal in the delta landscape and spread on the third geomorphic terraces. Also the zonal type of soils are Histosols where a significant amount of organic remnants accumulate. The delta soils contain up to $20 \mathrm{~kg} / \mathrm{m}^{2}$ and up to $40 \mathrm{~kg} / \mathrm{m}^{2}$ in permafrost. A large number of small thermokarst ponds allows to develop marsh ecosystems. Peat, in turn, has a low thermal conductivity, which does not allow the formation of a thick active layer in a short summer period, so new organic residues come in the soil year after year and are then deposited in permafrost. The last type of soils that was described on the island of Samoilovsky is Gleysols. This group develops on the middle and upper flood levels, on rocks of heavy texture, or near in places where permafrost spread. The group is characterized by a changing of oxidation-reduction reaction, an anaerobic environment is formed due to constant waterlogging where the ferrum valence changes $\left(\mathrm{Fe}^{3}-\mathrm{Fe}^{2}\right)$. This type of soil is typ- ical for zonal environment and could be considered as a zonal ones (Polyakov et al. 2017).

The next investigated island is ArgaBelir-Aryta, the soil catena is shown in Fig. 3.

On the island, three groups of soils were encountered, this is possibly related to its recent formation. Here the youngest soils prevail, in our opinion, this is due to a poor developed organo-accumulative horizon in all types of soils. During the spring moving ice and subsequent flood cuts the upper horizon, this action occurs annually and adversely affects soil formation. The height of the island is up to 16 meters, without big sharp increases and depressions. The island is located in the zone of the first and second flooding levels. The depth of the permafrost-affected soils rather high, up to $60 \mathrm{~cm}$, this is due to the fine texture of the local rocks and high aeration, the water here does not stagnate and the soil, which is mostly devoid of vegetation cover, warms up well in the summer.

Kurungnakh Island is one of the largest islands in the delta, it has been studied in detail in the north, east and south parts, which allows to determine with great accuracy its soil diversity. The western part is unexplored due to the low water level in the anabranches and remained inaccessible. The soil catena of the southern part of the island is presented in Fig. 4.

Kurungnakh Island is one of the oldest islands in the delta with a very diverse relief, the maximum height of the island is 66 meters, this figure is confined to mountain America Haya in the north of the island, where the graves of George De Long and members of his crew is located. On the island, 7 types of soils belong to 5 groups were found. The high elevation of the coast does not allow the formation of the Fluvisols, instead of it Umbrisols are formed near the shore, which indicates that the coastal zone in the past was flooded. 


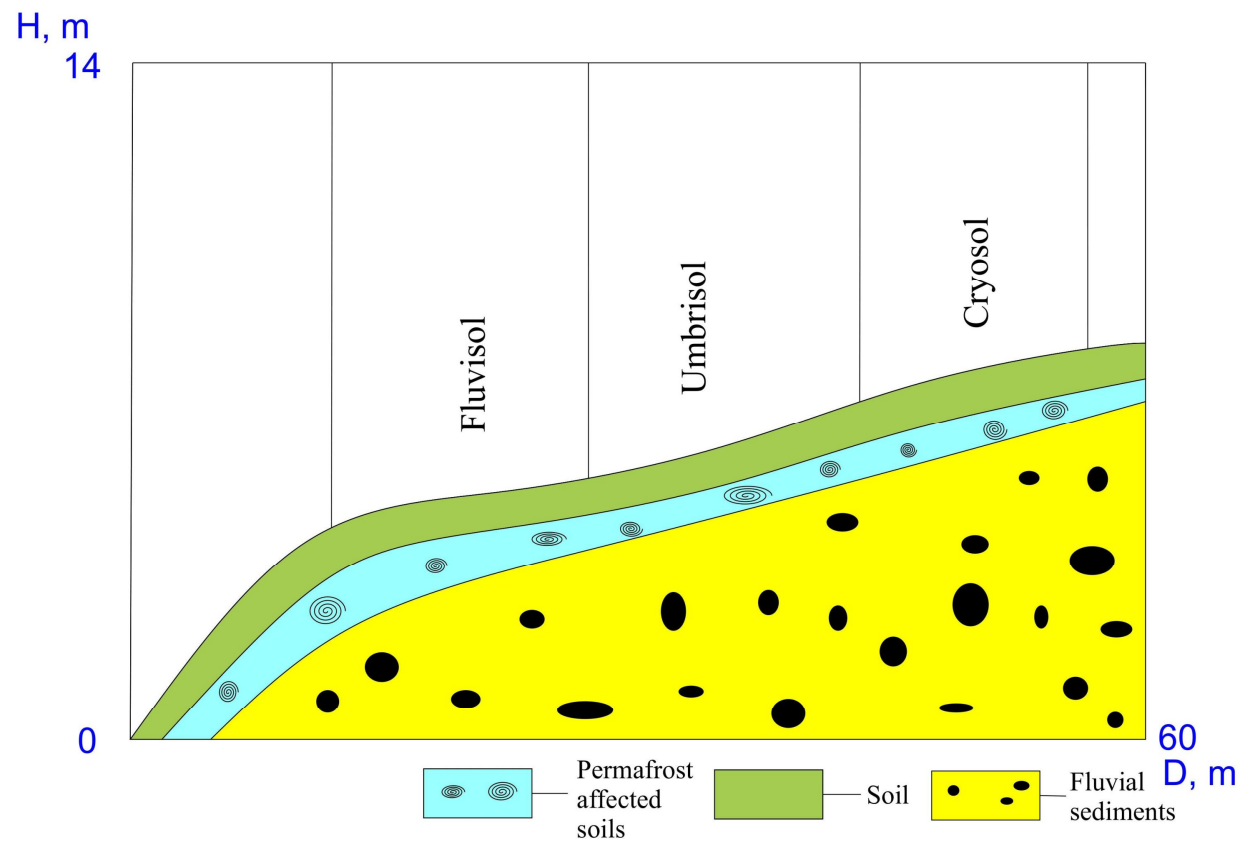

Fig. 3. The soil catena of Arga-Belir-Aryta Island.

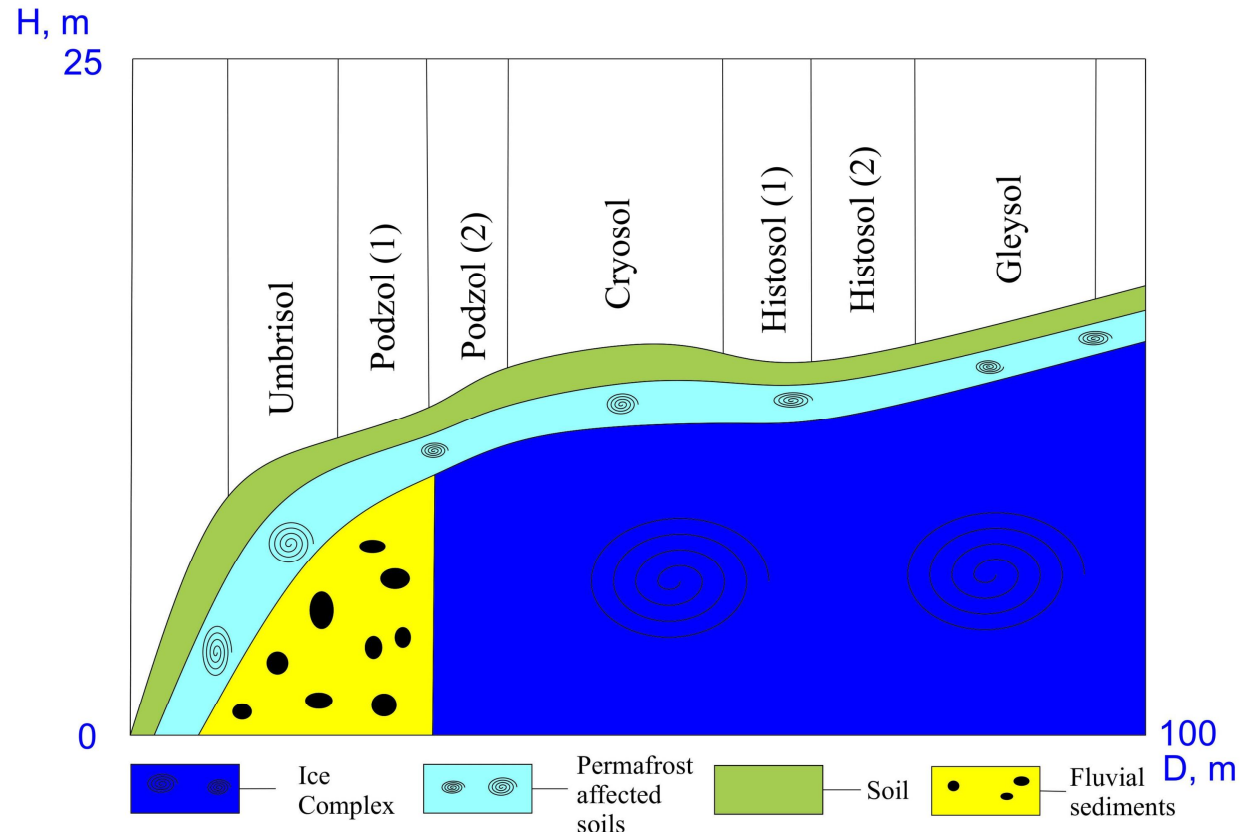

Fig. 4. Soil catena on Kurungnakh Island. 
In the coastal zone two subtypes of the Podzols group spread, the main difference between them is the thickness of organoaccumulative horizon, its formation may be associated with more favorable conditions for microorganisms.

Another type of soil that was observed is Cryosols. It locates on drained positions, near the occurrence of permafrost. Two subtypes of Histosol were found, they differ in the degree of decomposition of organic residues, in depressions the degree of decomposition is much lower than in the up- per positions. This is directly related to the groundwater level, in the depressions it is quite high due to the permafrost melting and water stagnation in depressions. Also Gleysols are presented. These soils locate near the occurrence of permafrost and have reducing reaction.

Hardang Island is also one of the most ancient islands in the delta. It is located in the zone of the first and second flooding levels and third terrace, composed by the sediments of the ice complexes terraces. Fig. 5 illustrates the soil catena.

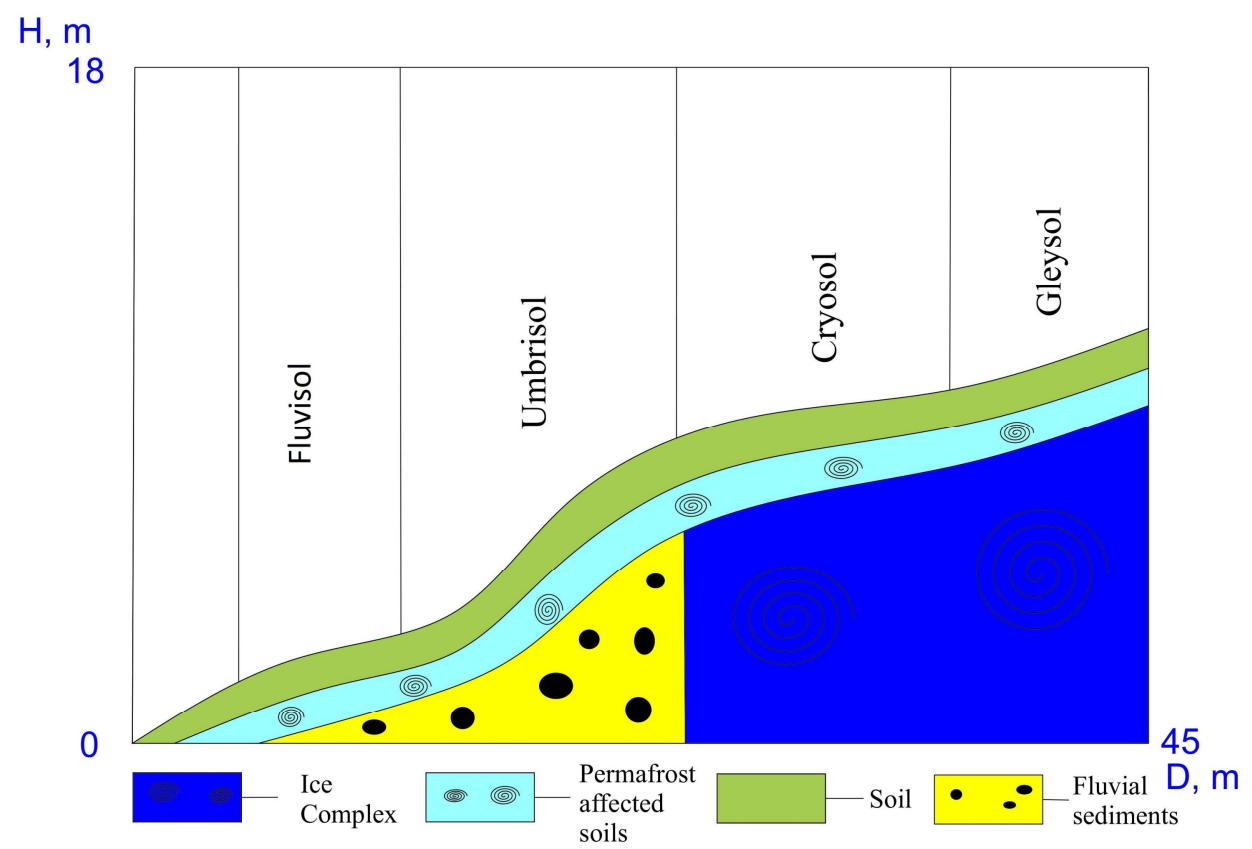

Fig. 5. The soil catena of Hardang Island.

Hardang Island was investigated in the southern and western parts, the soil diversity here is low, 4 soils types are represented. According to their genesis, they are similar to the soils of Samoilovsky Island, Fluvisols are distributed only in a small coastal zone. The island is mostly occupied by Cryosols and Gleysols soils. The active layer near the coastline reaches $60 \mathrm{~cm}$, in the area of the third geomorphological terrace it decreases to $25 \mathrm{~cm}$.

The soil diversity of the Lena River Delta is given on Fig. 6. 

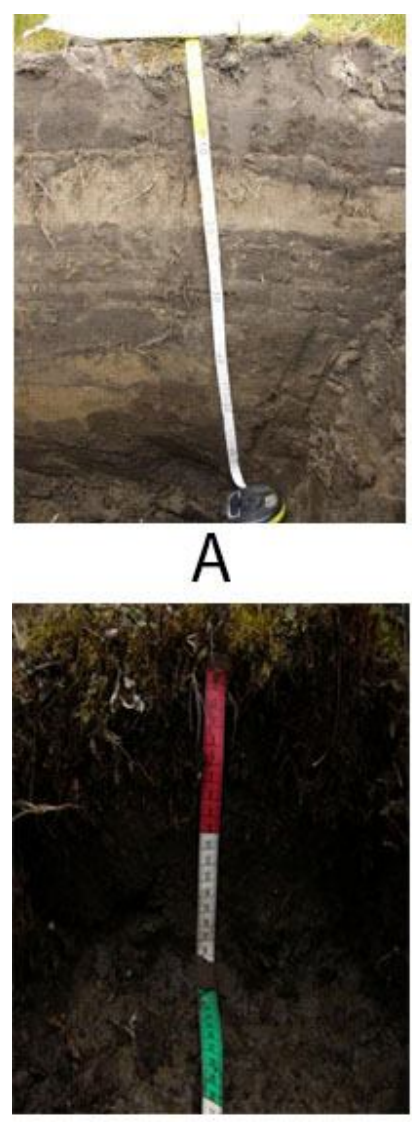

D

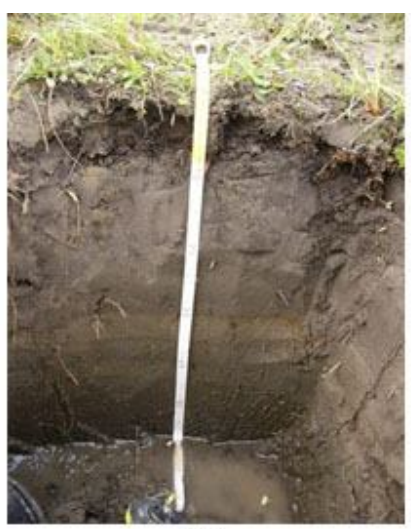

B

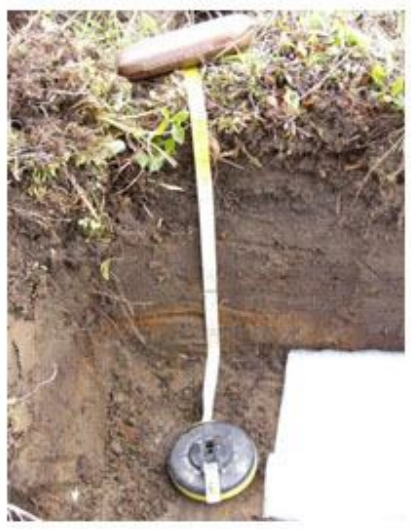

$\mathrm{E}$
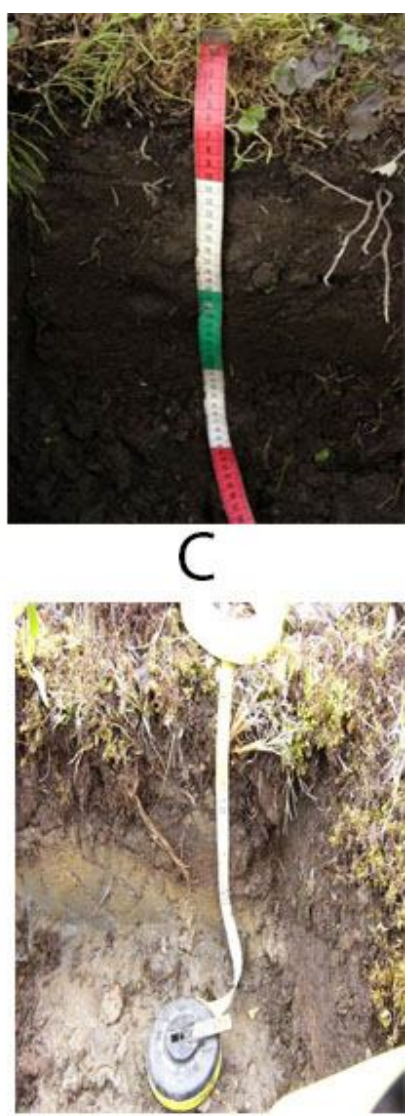

$\mathrm{F}$

Fig. 6. Soil diversity of study islands of the Lena River Delta. Note: A - Fluvisols, B - Umbrisols, C - Podzols, D - Cryosols, E - Histosols, F - Gleysols.

\section{Discussion}

Soil formation in the Arctic is closely related to the organic carbon deposition, accumulation and stabilization (Zubrzycki et al. 2013, 2014). The Lena River Delta soils accumulate up to $20 \mathrm{~kg} / \mathrm{m}^{2}$ in the active layer mostly within the Fluvisols group (Table 3). The annual inflow of alluvium and organic matter in the form of DOC cause the accumulation of a significant amount of organic material in the soil. In the alluvial soils buried organic horizons are frequently presented. According to the last studies, the soils of the Fluvisols group form in the large and small northern rivers' basins, they occupy about 42 million hectares, 20 in Siberia and the Far East (Dymov et al. 2013, Zubrzycki et al. 2013, Abakumov et Popov 2005, Dobrovolsky 2005, Dobrovolsky et al. 2011, Pipko 2010). Data of the laboratory analysis is presented in Table 2.

Previously, data on soil organic matter stocks has been published for soils of the same study sites (Polyakov et al. 2017). 


\begin{tabular}{|c|c|c|c|c|c|c|}
\hline Soil Group & $\mathbf{p H}_{\text {H2O }}$ & $\mathbf{p H}_{\text {CaC12 }}$ & $\begin{array}{c}\text { BR, mg CO }^{*} \\
\text { 100 }^{-1} \text { soil*h }^{-1}\end{array}$ & C (\%) & N (\%) & C/N ratio \\
\hline \multicolumn{7}{|c|}{ Samoilovsky Island } \\
\hline Fluvisols & 6.99 & 6.2 & $75.4 \pm 3.77$ & $1.39 \pm 0.06$ & $0.11 \pm 0.005$ & 12.6 \\
\hline Umbrisols & 6.41 & 5.85 & $27.5 \pm 1.37$ & $0.33 \pm 0.01$ & $0.05 \pm 0.002$ & 6.1 \\
\hline Podzols & 6.9 & 6.25 & $69.1 \pm 3.45$ & $0.53 \pm 0.02$ & $0.06 \pm 0.003$ & 8.8 \\
\hline Cryosols & 5.75 & 4.84 & $49.5 \pm 2.47$ & $3.21 \pm 0.16$ & $0.18 \pm 0.009$ & 17.7 \\
\hline Histosols & 6.45 & 5.32 & $150 \pm 7.5$ & $5.29 \pm 0.26$ & $0.3 \pm 0.015$ & 17.4 \\
\hline Gleysols & 5.94 & 4.6 & $143 \pm 7.15$ & $0.89 \pm 0.04$ & $0.08 \pm 0.004$ & 11.2 \\
\hline \multicolumn{7}{|c|}{ Arga-Belir-Aryta Island } \\
\hline Fluvisols & 5.49 & 4.39 & $50.3 \pm 2.51$ & $0.59 \pm 0.03$ & $0.06 \pm 0.003$ & 10.2 \\
\hline Umbrisols & 6.83 & 5.67 & $31.4 \pm 1.57$ & $0.33 \pm 0.01$ & $0.04 \pm 0.002$ & 7.22 \\
\hline Cryosols & 6.32 & 4.93 & $62.9 \pm 3.14$ & $2.23 \pm 0.11$ & $0.13 \pm 0.006$ & 17.1 \\
\hline \multicolumn{7}{|c|}{ Kurungnakh Island } \\
\hline Umbrisols & 7.41 & 6.68 & $38.5 \pm 1.92$ & $2.47 \pm 0.12$ & $0.19 \pm 0.009$ & 12.6 \\
\hline Podzols (1) & 7.1 & 6.23 & $66.1 \pm 3.3$ & $1.69 \pm 0.08$ & $0.13 \pm 0.006$ & 12.3 \\
\hline Podzols (2) & 5.33 & 4.35 & $44.1 \pm 2.2$ & $0.16 \pm 0.01$ & $0.03 \pm 0.001$ & 4.69 \\
\hline Cryosols & 5.59 & 5.7 & $38.5 \pm 1.92$ & $2.93 \pm 0.15$ & $0.22 \pm 0.01$ & 13.1 \\
\hline Histosols (1) & 5.84 & 4.37 & $54.3 \pm 2.71$ & $3.41 \pm 0.17$ & $0.23 \pm 0.01$ & 14.5 \\
\hline Histosols (2) & 5.46 & 4.37 & $69.9 \pm 3.49$ & $3.11 \pm 0.15$ & $0.19 \pm 0.009$ & 16.4 \\
\hline Gleysols & 5.76 & 3.79 & $25.1 \pm 1.25$ & $2.47 \pm 0.12$ & $0.15 \pm 0.007$ & 16.3 \\
\hline \multicolumn{7}{|c|}{ Hardang Island } \\
\hline Fluvisols & 7.18 & 6.38 & $62.9 \pm 3.14$ & $1.8 \pm 0.09$ & $0.14 \pm 0.007$ & 12.8 \\
\hline Umbrisols & 6.95 & 6.05 & $38.1 \pm 1.9$ & $0.93 \pm 0.05$ & $0.08 \pm 0.004$ & 11.6 \\
\hline Cryosols & 6.61 & 5.53 & $81.7 \pm 4.08$ & $2.62 \pm 0.13$ & $0.19 \pm 0.009$ & 13.8 \\
\hline Gleysols & 6.14 & 5.01 & $69.1 \pm 3.45$ & $4.47 \pm 0.22$ & $0.36 \pm 0.01$ & 12.4 \\
\hline
\end{tabular}

Table 2. Chemical characteristics of soils from other islands of the Lena River Delta. Soils were analyzed from upper layer $(0-20 \mathrm{~cm})$. Note: $\mathrm{BR}$ - basal respiration, $\mathrm{mgCO}_{2} / 100 \mathrm{~g}^{*} \mathrm{day}^{-1}$, with mean $\pm \mathrm{SD}$ for $\mathrm{BR}, \mathrm{C}$ and $\mathrm{N}$ content.

An accumulation of various form of organic matter transported by river is a key pedogenic process in large northern deltas. Depending on the speed of the water flow during flooding, either clay particles or sandy deposit, in connection with this formation of stratificated soils occurs. The for- mation of soils in the areas of distribution of rivers primarily depends on the age and sediments. Deltas and its soils are dynamic in time. Alluvial and flooding processes replaced by the process of zonal soil formation. It should be noted that most of the soils in the areas of northern rivers are oc- 
cupied by Cryosols, this is due to the presence of permafrost. In the depressions peat soils and soils with signs of gleying form. The formation of soils with a thick organic-accumulative horizon can be linked with the income of available for decomposition organic residues with river waters, as well as with favorable conditions for microor- ganisms activity. With the water flow a large number of biogenic elements enter the soil, which positively affects the humus formation (Pereverzev et Litvinova 2010, Tigeyev 2014, Dyukarev 2005, Motorin et Bukin 2012). Cryoturbation and related cryogenic mass exchange appear maingly on the places of ice complexes prevailing.

\begin{tabular}{|c|c|}
\hline Soil Group & Estimated carbon stocks, $\mathrm{kg} / \mathrm{m}^{2}$ \\
\hline Fluvisols & $20 \pm 1$ \\
\hline Umbrisols & $18 \pm 0.9$ \\
\hline Podzols & $16 \pm 0.8$ \\
\hline Cryosols & $12 \pm 0.6$ \\
\hline Histosols & $13 \pm 0.65$ \\
\hline Gleysols & $15 \pm 0.75$ \\
\hline
\end{tabular}

Table 3. Carbon stocks in different soil group. Mean \pm SD.

The profile distribution of soils in space is closely related to the influence of the river hydrology. Peat soils are formed in depressions; activity of zonal processes and the formation of Cryosols are observed at well drained positions. Depending on the distance from the river, the implementation of zonal processes of soil formation is higher. In areas prone to flooding, sinlithogenic soils formation takes place with a pronounced stratification of soil horizons. As a result of stratification of soil horizons in soils, a large amount of organic carbon is deposited (Bischoff et al. 2013, Kutzbach et al. 2004, Knoblauch et al. 2013, Preuss

\section{Conclusions}

Topographic soil profiling is the most convenient way of studying soil formation in case of tundra ecosystems because soils in this type environment are very dependent of geogenic factors. As a result of our research, conducted profiles were obtained et al. 2013, Wagner et al. 2007, Evgrafova et al. 2010).

The mild maritime climate and the activity of the river direct the process of soil formation into the podzolization type, in connection with this, the accumulation of aromatic compounds in the soil and, accordingly, the stabilization of organic matter. Depending on the degree of manifestation of the zonal processes, the processes of podzolization become cryogenic (Davidson et Janssens 2006, Lodygin et al. 2014, Dziadowiec et al. 1994, Abakumov et al. 2015).

and characterized for 4 islands of the Lena River Delta. Soils are represented by the following groups: Fluvisols, Umbrisols, Podzols, Cryosols, Histosols, Gleysols. They are closely related to the flooding levels of the delta. The first flooding level (flood 
meadows) includes soils associated with alluvial material accumulation and the most developed soils here are the Fluvisols. The soil cover of the second and the third geomorphological levels are characterized by increased pedodiversity. In the depressions there is evident development Histosols and Gleysols. These soils are in a hydromorphic condition for most of the time. The soils of the Podzols and Cryosols groups are common on drained sites. The process of migration of iron and aluminum oxides within the Podzols group and their accumulation on the boundary with permafrost occure within the Podzols group. Cryosols are characterized by the development of cryoturbation, thixotropy and cryogenic mass exchange. Soil development and landscape formation are interrelated processes that take place in space and time. The study of landscape positions can shed light on the laws of development of soils and vice versa.

\section{Reference}

ABAKumov, E., Lodygin, E. and TomashunAs, V. (2015): ${ }^{13}$ C NMR and ESR characterization of humic substances isolated from soils of two siberian Arctic islands. International Journal of Ecology, Article ID 390591, pp. 1-7.

Abakumov, E. V., Popov, A. I. (2005): Determination of the carbon and nitrogen contents and oxidizability of organic matter and the carbon of carbonates content in one soil sample. Eurasian soil science, 2: 165-172.

Antonov, V. S. (1957): Distribution of river waters in the Arctic seas. AARI, 2: 25-52. (In Russian).

Bischoff, J., Mangelsdorf, K., Gattinger, A., Schloter, M., Kurchatova, A. N., Herzschuh, U. and WAGNER, D. (2013): Response of methanogenic archaea to Late Pleistocene and Holocene climate changes in the Siberian Arctic. Global Biogeochemical Cycles, 27: 305-317.

Boike, J., Kattenstroth, B., Abramova, K., Bornemann, N. , Chetverova, A. , Fedorova, I. , Fröb, K. , Grigoriev, M. , Grüber, M. , Kutzbach, L. , Langer, M. , Minke, M. , Muster, S. , Piel, K. , Pfeiffer, E. M. , Stoof, G. , Westermann, S. , Wischnewski, K. , Wille, C. And HubBerten, H. W. (2013): Baseline characteristics of climate, permafrost and land cover from new permafrost observatory in the Lena River Delta, Siberia (1998-2011). Biogeosciences, 10: 2105-2128, doi: 10.5194/bg-10-2105-2013.

Bolshiyanov, D. Y., Makarov, A. S., Schneider, V. and Shtof, G. (2013): Origin and Development of the delta Lena River.- St. Petersburg: AARI, 268 p. (In Russian).

CAUWET, G., SidOROV, I. (1996): The biogeochemistry of Lena river: Organic carbon and nutrients distribution. Marine Chemistry, 53: 211-227.

DAVIDSON, E. A., JANSSENS, I. A. (2006): Temperature sensitivity of soil carbon decomposition and feedbacks to climate change. Nature, 440: 165-173.

Dobrovolsky, G. V. (2005): Soils of the floodplains of the center of the Russian Plain. 2-nd ed., Pererab. And additional. - Moscow: Izd-vo MGU, 293 p. (In Russian).

Dobrovolsky, G. V., Balabko, P. N., Stasyuk, N. V. and Bykova, E. P. (2011): Alluvial soils of river floodplains and deltas and their zonal differences. Arid Ecosystems, 17.3(48): 5-13. (In Russian).

Dymov, A. A., Kaverin, D. A. and Gabov D.N. (2013): Properties of soils and soil-like bodies of the city of Vorkuta. Pochvovedeniye, 2: 240-248. (In Russian).

DYukAREV, A. G. (2005): Landscape-dynamic aspects of taiga soil formation in Western Siberia. Tomsk: Publishing house of NTL, 284 p. (In Russian).

Dziadowiec, H., Gonet, S. and Plichta, W. (1994): Properties of humic acids of Arctic tundra soils in Spitsbergen. Polish Polar Research, 15: 71-81.

Evgrafova, S. Y., Grodnitskaya, I. D., Krinitsyn, Y. O., Syrtsov, S. N. and Masyagina, O. V. (2010): Emission of methane from the soil surface in the Tundra and forest ecosystems of Siberia. Bulletin of Krasnoyarsk State University, 12: 80-86. (In Russian). 
GaLABALA, R.O. (1987): New data on the structure of the Lena delta.Quaternary The period of Northeast Asia. Magadan: SVKNII of the Far Eastern Branch of the Academy of Sciences of the USSR, pp. 125-171. (In Russian).

IVANOV, V. V. (1963): Stok and currents of the main streams of the Delta River Lena. AARI, 5: 7686. (In Russian).

Kimble John M., Follett Ronald F. (2001): Assessment methods for soil carbon. Edited by: R. Lal, John M. Kimble, Ronald F. Follett, B.A. Stewart. Published in Lewis Publishers, 696 p.

Knoblauch, C., Beer, C., Sosnin, A., Wagner, D. and Pfeiffer, E.-M. (2013): Predicting longterm carbon mineralization and trace gas production from thawing permafrost of Northeast Siberia. Global Change Biology, 19: 1160-1172.

Kutzbach, L., Wagner, D. and Pfeiffer, E. M. (2004): Effect of microrelief and vegetation on methane emission from wet polygonal tundra, Lena Delta, Northern Siberia. Biogeochemistry, 69: 341-362.

Lara, R. J., Rachold, V., Kattner, G., Hubberten, H. W., Guggenbergen, G., Skoog, A. and Thomas, D. N. (1998): Dissolved organic matter and nutrients in the Lena River, Siberian Arctic: Characteristics and distribution. Marine Chemistry, 59: 301-309.

Lodygin, E. D., Beznosikov, V. A. and VAsilevich, R.S. (2014): Molecular composition of humic substances in tundra soils $\left({ }^{13} \mathrm{C}-\mathrm{NMR}\right.$ spectroscopic study). Eurasian Soil Science, 47 : 400-406.

Motorin, A. S., Bukin, A. V. (2012): The content of cadmium and lead in alluvial soils of the Northern Transural Region. Agrarian Bulletin of the Urals, 9(101): 63-67. (In Russian).

NechaeVA, Y.G. (1994): Landshaftno - geochemical zoning of Yakutia. Geography and Natural Resources, 4: 104-112. (In Russian).

Pereverzev, V. N., Litvinova, T. I. (2010): Soil-sea terraces and aboriginal slopes on the coasts of the fjords of the Western Spitsbergen Island. Pochvovedenie, 3: 259-269. (In Russian).

Pesterev, A. P. (2013): Soil cover of Western Yakutia. Vestnik of the NEFU, 3:10-17. (In Russian).

Pipko, I. I., Pugach, S. P., Dudarev, O. V., Charkin, A. N. and Semiletov, I. P. (2010): Carbonate Parameters of the Lena River Water: Characteristics and Distribution. Geochemistry, 11: 1206-1213. (In Russian).

Polyakov, V. I., Orlova, K. S. and ABakUmov, E.V. (2017): Evaluation of carbon stocks in the soils of Lena River Delta on the basis of application of "dry combustion" and Tyurin's methods of carbon determination. Biological communications, 62(2): 67-72.

Preuss, I., Knoblauch, C., Gebert, J. and Pfeiffer, E.-M. (2013): Improved quantification of microbial $\mathrm{CH}_{4}$ oxidation efficiency in arctic wetland soils using carbon isotope fractionation. Biogeosciences, 10: 2539-2552.

Schneider, J., Grosse, G. and Wagner, D. (2009): Land cover classification of tundra environments in the Arctic Lena Delta based on Landsat 7 ETM+ data and its application for upscaling of methane emissions. Remote Sensing of Environment, 113: 380-391.

Tigeyev, A. A. (2014): Peculiarities of the soil cover of the Khilmigyakha river basin (NadymPurov interfluve). Bulletin of the Tyumen State University, 4: 39-48. (In Russian).

Wagner, D., Gattinger, A., Embacher, A., Pfeiffer, E.-M., Schloter, M. and Lipski, A. (2007): Methanogenic activity and biomass in Holocene permafrost deposits of the Lena Delta, Siberian Arctic and its implication for the global methane budget. Global Change Biology, 13: 1089-1099.

Zubrzycki, S., Kutzbach, L., Grosse, G., Desyatkin, A. and Pfeiffer, E.-M. (2013): Organic carbon and total nitrogen stocks in soils of the Lena River Delta. Biogeosciences, 10:3507-3524.

Zubrzycki, S., KutZBach, L. and Pfeiffer, E.-M. (2014): Permafrost-affected soils and their carbon pools with a focus on the Russian Arctic. Solid Earth, 5: 595-609.

\section{Web sources / Other sources}

[1] WRB - World Reference Base of Soil Resources (2014): World soil resources report, No. 106, FAO, Rome. 